\title{
WRITING PERFORMANCE OF ISLAMIC UNDERGRADUATE STUDENTS IN THE ISSUES OF INTEGRATION TECHNOLOGY AND LANGUAGE LEARNING
}

\author{
Nur Rahmiani \\ nur.rahmiani15@gmail.com \\ English Lecturer at Faculty of Shariah, Institut Agama Islam Negeri Pontianak
}

\begin{abstract}
This work aims at measuring the performance of students in writing an essay in three critical aspects, namely the material of the writing, comprehension aspect, and student's feedback. The essay comes from a mid-term writing test for Islamic undergraduate students using content that relates to the student's field of expertise. The data is analysed using a mixed method that is descriptive quantitative-qualitative. First, the authors utilize a premium online application to notice the extent of correctness, clarity, engagement, delivery, and readability. Second, the author explores information about student's response to the implications of integration technology in language learning with the Grammarly online as an automatic-evaluation writing performance. The results signify that the issue of correctness mostly appears with an average value of 24.3 or 292 cases in a total of 593 material writing problems. The other hands, the quality of writing based on the readability score shows that most of the writing is more suitable to be read by at least readers with the senior high school levels (10th grade-students). It is in contrast with the level of education who made the essay. Student feedback emphasises the suitability of applying Grammarly in language learning both individually and in a working group. Suggestion for education managements is that every student from various major needs to improve the quality of writing, of course, by involving qualified lecturers and appropriate applications. In the future, the utilization of teaching-learning technology in English writing is needed and strengthened with lecturer guidance.
\end{abstract}

Keywords: Teaching-Learning Technology, Grammarly, Writing Performance.

\section{A. INTRODUCTION}

The globalization era has taken human beings to the period where they are more globally connected. This connection deforms human beings living in what socalled "global village" (L.R. Kurtz, 2007) today. It grows as fast as the fast development of information and telecommunication technology that gets wide and high competitions in many different aspects of human life including educational system (Ann-sofi Israelsson, Mogens Sandfaer, and Stephan Schwarz, 1991). The system is no longer rigid and monotonous because the method and technique can be varied and not rarely in a conventional way like teacher-centred method. Computer and its stuff could offer various and simpler ways such as a friendly media for teachers or lecturers as well as for students themself, (Chris Pim, 2013).

Several studies reveal that the integration of computers and technologies provide positive effects on the primary actors of educational characterization. Ghavifekr and Rosdy, (2015) in their research, notice that ICT (Information and Communication and Technology) offer a significant impact, notably if the teacher 
provides well-preparing of the equipment and facilities. The use of technology also enhances a convenient academic atmosphere since it supports students with audio-visual schemes and illustrations, monitoring progresses, and students' achievement, (Kesh Bahadur Rana, 2017). Technology is also considered as a method that motivates students with a learning exposure, like aural and visual environment, (Hassina Nachoua, 2012). Furthermore, in academic matters, utilising technologies is a great value to give countenance to assessment processes. ICT provides students to access unimpeded timing learning program even an automatically evaluation which has a potential impact on the assessment feedback and also repeating kind of exercises in any time as needed, (Russell Stannard and Anthony, 2013).

The author notices a research problem strengthening in the issues of Computer Assisted Language Learning (CALL) to writing performance for Islamic undergraduate students in Pontianak. At least there are three logical reasons for this study. First, substantially, English is recognised as the world' social language (lingua franca) that needs reconsidering inside classroom practices as a foreign language, (Gillian Mansfield and Franca Poppi, 2012). It has been internalised in the educational system in Indonesia which is proven by the position of English course as one part of the structure of the institutional and faculty curriculum whether in general state and Islamic tertiary institutions, (Ichsan Iqbal and others, 2017). It means that there is a real effort form the Islamic collage to strengthen international competitiveness through EFL learning that demands holistic academic achievements.

Second, in practice, based on the impact of the industrial revolution 4.0 is that students allowed being able to combine the two exceptional abilities named cognitive and motoric aspect to learn by using technological tools. In this case, as an Islamic undergraduate student, the ability to read English texts relating to the major and then paraphrase them into writing as part of learning references is a positive impact of the use of industrial revolution. However, a lot of quality English texts are digitalised in internet sources which loss to be left.

Third, in real, students challenge many difficulties in the writing aspect. This complication occurs since the students write their identity. Written material by students has spelt out that the quality of the contents of their thought is powerless. Common errors still occur in grammatical aspect as straightened in the several research of language learning, (Saiful Bahri and Bambang Sugeng, 2009). The preliminary study indicates that at least $25 \%$ of the total students who have well enough proficiencies. Then, when the lecturer allows students to the mid-term test in the group-working with integrating one of the CALL program, namely Grammarly, the students' conscious of doing their assignment.

Grammarly is free online software that has many features like an automatically evaluation writing programs (G. Lorena Parra and S. Ximena Calero, 2019) such as grammar controller, a plagiarism indicator and some vocabulary improvement suggestions, (Bryan Collins , 2020). People can use a paid account named Grammarly Premium. Like free access, it provides not only information about each of writing mistakes in the attention box more detail but also offers extra writing judgments in a set of writing goals. It means that it is better if the user prefers the paid one. However, if the user has a problem with the price, Grammarly can still work as proper as its function even though in free used.

Grammarly has a significant reduction in error and improving writing quality, (Muhammad Ali Ghufron and Fathia Rosyida, 2018). Thus, it is easy for students to instruct their writing in terms of grammar, spelling, and punctuation, even to the stages of engagement, clarity, and 
delivery. Grammarly also accommodates the readability score; somehow, the language can be apprehensible, (William $\mathrm{H}$ Dubay , 2004). Grammarly correction results are considered able to evolve the quality of student writing performance, ( $\mathrm{J}$ M Dembsey, 2017). Students become mindful of which parts should be repaired and which sections are not and still need their teacher's feedback while assessing their writing with Grammarly, (Abolfazl Qassemzadeh and Hassan Soleimani, 2016).

This article certainly has a difference from previous studies since the research study is the written material and reading comprehension and how the evaluation of students on the use of Grammarly in groups in an essay writing program. This program is a form of midterm exam assignments at Islamic higher education, named The State Institute of Islamic Studies of Pontianak (IAIN Pontianak), West Kalimantan. The researcher examines what writing performance issues arose mostly, how the quality of their writing from the aspect of readability, and student responses to the sustainability of integrated learning programs with technology carried out in groups.

This study uses a qualitative and quantitative descriptive approach by analysing students' written materials through a figure of their writing performance. To illustrate the performance of writing, the author describes several essential things, namely 1) material writing aspects consisting of engagement, correctness, clarity, and delivery; and 2) comprehension aspects, namely the level of readability. Therefore, the author collects the research evidence through the interview process, literature study, analysis of essay documents both through direct observation and by computer-assisted language learning using Grammarly Premium-online application. The author also triangulates data in order to ensure there is no biased. For the number of participants, the author involves Shariah Economic Law students of IAIN Pontianak amounting to 60 persons, consisting of three class groups, where each class group has four small groups as the essay compilation team. The participant had previously succeeded in making essay papers with four different themes, namely corruption, collusion, nepotism, and justice, thus that the number of documents analysed amounted to 12 works of essays. They have also translated the writing using English dictionaries, both hard-book and online. Students have also corrected the performance of their manuscript using the Grammarly free-used application. At the end of the session, students give feedback from their automated-correction covering three questions, namely 1) Assessment of the automated-correction process that has been done in groups, 2) The benefits, and 3). The need for continued use of Grammarly as a learning tool for writing.

\section{B. DISCUSSION}

The author describes The findings of this research by such evaluation outputs to answer the research questions. The evaluation consists of three critical ideas, namely the material writing aspect, the comprehension aspect, and the feedback automatic-correctness from students.

\section{Material Writing Aspect}

In this part, the author looks with attention to four aspects of Grammarly analysis, namely engagement, correctness, clarity, and delivery. The engagement refers to the exciting and compelling scores of passage by passage in writing an essay. Correctness is about the use of grammar, spelling, and punctuation. How students combine those components of engagement to compile an essay with absolute regularity. Clarity means that the writing is easier to understand by the readers. Then, delivery refers to how the reader gets the right impression from the students writing. Here there are the total 
Tabel 1. The Cases of Material Writing Aspect

\begin{tabular}{lccccc}
\hline Number of Essays & Engagement & Correctness & Clarity & Delivery & Total Cases \\
\hline Doc1 & 4 & 24 & 21 & 2 & 51 \\
\hline Doc2 & 10 & 21 & 9 & 2 & 42 \\
\hline Doc3 & 3 & 31 & 19 & 3 & 56 \\
\hline Doc4 & 2 & 18 & 15 & 8 & 43 \\
\hline Doc5 & 8 & 14 & 11 & 0 & 33 \\
\hline Doc6 & 1 & 34 & 23 & 4 & 62 \\
\hline Doc7 & 3 & 31 & 19 & 3 & 56 \\
\hline Doc8 & 2 & 18 & 15 & 8 & 43 \\
\hline Doc9 & 4 & 26 & 16 & 2 & 48 \\
\hline Doc10 & 6 & 36 & 18 & 1 & 61 \\
\hline Doc11 & 8 & 13 & 7 & 2 & 30 \\
\hline Doc12 & 7 & 26 & 28 & 7 & 68 \\
\hline Total Cases & $\mathbf{5 8}$ & $\mathbf{2 9 2}$ & $\mathbf{2 0 1}$ & $\mathbf{4 2}$ & $\mathbf{5 9 3}$ \\
\hline Maximal Score & $\mathbf{1 0}$ & $\mathbf{3 6}$ & $\mathbf{2 8}$ & $\mathbf{8}$ & $\mathbf{6 8}$ \\
\hline Minimal Score & $\mathbf{1}$ & $\mathbf{1 3}$ & $\mathbf{7}$ & $\mathbf{0}$ & $\mathbf{3 0}$ \\
\hline Mean Score & $\mathbf{4 , 8}$ & $\mathbf{2 4 , 3}$ & $\mathbf{1 6 , 8}$ & $\mathbf{3 , 5}$ & $\mathbf{4 9 , 4}$ \\
\hline Sources: Grammarty & $\mathbf{4}$ & & & \\
\hline
\end{tabular}

Sources: Grammarly Statistical Analysis (2020)

Based on table 1, it was 593 cases of writing issues regarding the written material of students. Most cases are in the aspect of correctness with some 292 cases (49.2\%). That is, almost most students have limitations in placing grammar, spelling, and punctuation. For the average score of cases per aspect sequentially starting from engagement, correctness, clarity, and delivery are 4.8, 24.3, 16.8, and 3.5 with the most cases incorrectness and the least cases are delivery issues. The display of writing performance from Grammarly analysis can be seen in figure 1.

\begin{abstract}
Justice is a condition of moral ideality of things, whether it is related to things or people. According to most theories, justice has a large degree of interest. John Rawls, a philosopher of the United States who is considered one of the foremost political philosophers of the 20th century, stated that "Justice is the first virtue of social institutions, how is truth in systems of thought'1 But according to most theories too, justice has not yet been achieved: "We do not live in a just world" 2 most people believe that injustice must be resisted and punished, and many social and political movements throughout the world are struggling to uphold justice. But, the large number and variety of theories of justice for thinking that it is not clear what is demanded from justice and the reality of injustice because of the definition of whether justice itself is not clear. This justice puts everything in its place.
\end{abstract}

So from the above understanding, we can conclude that according to John Rawls justice is always demanded throughout the world, it's just that justice is still difficult to obtain. Because of what? This is because there aro ctill manu nomo in a country whn ctill don not undorctand tho law with

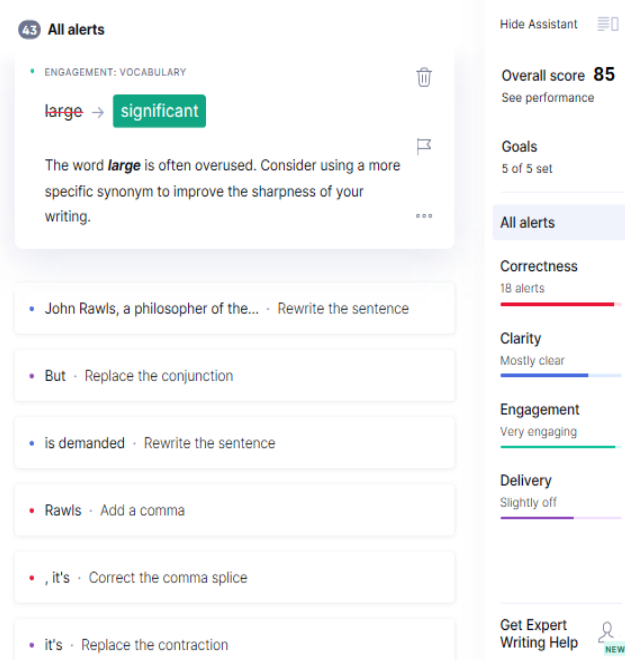

Figure 1.The Screenshot Grammarly Analysis of Writing Performance 


\section{Comprehension Aspect}

In this part, the author reveals the readability score of writing performance. This score is the result of online Grammarly analysis by looking at the length of words and sentences; thus that the conclusions appear those who are the proper target readers can read and understand these written materials. The range of words means the number of items in each word while the length of sentences means the total of bits in each sentence. These scores impress the readability score, which has a meaning that the sentences have a legible quality to read for any reader.

Tabel 2. The Case of Comprehension Aspect

\begin{tabular}{lllll}
\hline $\begin{array}{c}\text { Number of } \\
\text { Essays }\end{array}$ & $\begin{array}{c}\text { Word } \\
\text { Length }\end{array}$ & $\begin{array}{c}\text { Sentence } \\
\text { Length }\end{array}$ & $\begin{array}{c}\text { Readability } \\
\text { Score }\end{array}$ & Conclusion \\
\hline Doc1 & 5 & 17.9 & 47 & Readers are at least $10^{\text {th }}$-grade education students (16 yo) \\
\hline Doc2 & 5.1 & 17.4 & 36 & Readers are at least college education students \\
\hline Doc3 & 5.3 & 22.9 & 29 & Readers are at least college education students \\
\hline Doc4 & 4.8 & 20 & 53 & Readers are at least $9^{\text {th }}$-grade education students (15 yo) \\
\hline Doc5 & 5 & 25.2 & 38 & Readers are at least college education students \\
\hline Doc6 & 5.3 & 25.6 & 26 & Readers are at least college education students \\
\hline Doc7 & 4.8 & 24 & 43 & Readers are at least $10^{\text {th }}$-grade education $(16$ yo) \\
\hline Doc8 & 4.7 & 26.1 & 48 & Readers are at least $10^{\text {th }}$-grade education $(16$ yo) \\
\hline Doc9 & 5 & 19.3 & 47 & Readers are at least $10^{\text {th }}$-grade education $(16$ yo) \\
\hline Doc10 & 5 & 22.4 & 36 & Readers are at least college education students \\
\hline Doc11 & 4.9 & 14.6 & 29 & Readers are at least $10^{\text {th }}$-grade education students $(16$ yo) \\
\hline Doc12 & 5.1 & 15.7 & 53 & Readers are at least $10^{\text {th }}$-grade education students $(16$ yo) \\
\hline
\end{tabular}

Sources: Grammarly Statistical Analysis (2020)

Based on table 2, the data shows that the level of readability score from written students' material is classified sequentially in the range of 9th-grade education level about 1 document $(8.3 \%)$, 10th-grade education level about six documents $(50 \%)$, and college graduated students about five documents (41.7)\%. These results are revealed based on the metrics compared to other users of Grammarly application. Then, the display of the readability score can be seen in figure 2 below.
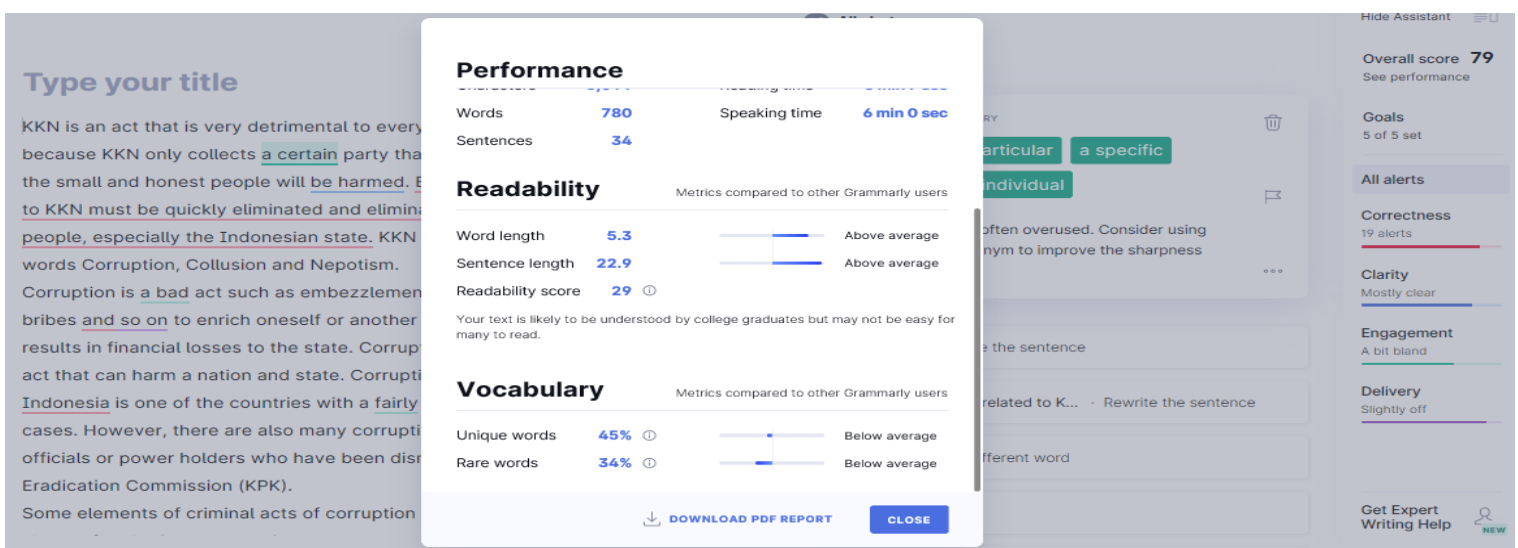

Figure 2. Readability Score by Grammarly Analysis 


\section{Feedback automatic-correctness form students}

Below is a summary of answers to critical questions to find out the feedback from students as a basis for improving the learning process of writing English. Three questions stressed to the students perspective interpret about 1) technical assessment of the use of Grammarly in group work, 2) the benefits of using Grammarly online in terms of group work, and 3) the need of the sustainability Grammarly use in writing learning process. Here, table 3 shows the answers to these questions.

Tabel 3. The Students' Feedback

\begin{tabular}{|c|c|c|c|}
\hline No & $\begin{array}{l}\text { Assessment of group-works } \\
\text { automated-correction } \\
\text { process using Grammarly }\end{array}$ & $\begin{array}{l}\text { The benefits of group work } \\
\text { automated-correction process } \\
\text { using Grammarly }\end{array}$ & $\begin{array}{l}\text { The need for sustainability } \\
\text { process of Grammarly use as a } \\
\text { learning tool for writing }\end{array}$ \\
\hline 1 & $\begin{array}{l}\text { An application that is very } \\
\text { interesting and useful for those } \\
\text { who are weak in English. }\end{array}$ & $\begin{array}{l}\text { Proofing literary works } \\
\text { automatically. Thus, the benefit is } \\
\text { that if there is a wrong sentence, } \\
\text { Grammarly directly bring up a } \\
\text { warning sign. }\end{array}$ & $\begin{array}{l}\text { The balance between learning } \\
\text { without and using technology } \\
\text { needs to be followed up. }\end{array}$ \\
\hline 2 & $\begin{array}{l}\text { An application that is easy and } \\
\text { practical to be used } \\
\text { independently or in groups } \\
\text { only needs to consider the } \\
\text { balance of the learning process } \\
\text { that takes place naturally like } \\
\text { conventional methods in } \\
\text { general. After all, the role of } \\
\text { the English teacher is far more } \\
\text { memorable than purely using } \\
\text { technology because language } \\
\text { learning requires } \\
\text { communication. }\end{array}$ & $\begin{array}{l}\text { Sharing opinions through the group } \\
\text { work system is primary, although, } \\
\text { in reality, not all teams can be } \\
\text { actively involved. }\end{array}$ & $\begin{array}{l}\text { Sustainable use of this application } \\
\text { very needs to be maintained, but } \\
\text { there must be assistance from the } \\
\text { teacher during the guidance } \\
\text { process of writing. }\end{array}$ \\
\hline 3 & $\begin{array}{l}\text { An application that is like a } \\
\text { shortcut system and can } \\
\text { quickly point out writing } \\
\text { errors even though in reality, } \\
\text { many corrections from } \\
\text { Grammarly cannot be } \\
\text { followed up because students } \\
\text { have not mastered English } \\
\text { enough. }\end{array}$ & $\begin{array}{l}\text { The statement "writing English for } \\
\text { everyone" can be done not only for } \\
\text { students who are from English } \\
\text { education majors but also for all } \\
\text { students from any major. }\end{array}$ & $\begin{array}{l}\text { Providing premium Grammarly } \\
\text { access is optimal sustainability. }\end{array}$ \\
\hline 4 & $\begin{array}{l}\text { Grammarly is more suitable } \\
\text { for use individually. }\end{array}$ & $\begin{array}{l}\text { Both learning collaboration and } \\
\text { communication through group } \\
\text { work processes in discussing the } \\
\text { writing issues of Grammarly } \\
\text { correction is one of the benefits of } \\
\text { using Grammarly. }\end{array}$ & $\begin{array}{l}\text { Peer-group discussions ( } 2 \text { people) } \\
\text { explicitly learning to write are } \\
\text { much better for the sustainability } \\
\text { of learning using Grammarly } \\
\text { online. }\end{array}$ \\
\hline
\end{tabular}

\section{Sources: Data Interviews Analysis (2020)}

The qualitative data findings were obtained by analysing several interview results. Four critical findings from each of the essential questions are related to feedback on the use of Grammarly in groups on essay writing assignments. This result is also an evaluation of automatic correctness writing learning by CALL, whether it can be sustained with all important notes attached to the findings.

From those three discussion aspects, evaluating the teaching and learning process in the classroom is a compulsion for every teacher and lecturer. The 
evaluation results may affect the sustainability of learning in the cycles of learning. All matters related to learning, including technologies, should also be assessed whether the effectiveness and efficiency for the learning output and outcome, which kind of method, technique, and a project that could be chosen as appropriate as what pretension in learning outcomes.

Dealing with CALL, the author explains that students get excellent facilitation through technology learning; thus that what is considered impossible in writing English becomes might otherwise because of digital assistances. Technology and its equipment have a ritme to undertake the problematic parts of how language learning have done. This statement is strengthened by research that CALL provides positive effects to the primary actors of the teaching and learning process, teachers and students if the teacher includes preparing-well of the equipment and facilities (Ghavifekr and Rosdy, 2015). The use of technology also enhances student's motivation(Hassina Nachoua, 2012), a complex audio-visual teaching media in monitoring student progres, and student achievements, (Kesh Bahadur Rana, 2017). Wang and Liao also discover that utilising CALL and innovative, collaborative learning is more effective than using traditional collaborative learning in enhancing English proficiencies of students.

The participants use Grammarly as software that supports learning English, focusing on writing skills. Grammarly provides a brainy and artificial language learning machine to help learners in writing, from necessary spelling, style and grammar, and to more preferred and appropriate language uses as like as a reliable proofreader, (Denys Krasnikov, 2018). Grammarly can help students improve their writing skills by designing a new computer program with an automatic grading system (Parra and Calero). Grammarly also has various benefits such as providing different codes to offer evaluations to users both in the form of explanations and examples, making it easier for users to access and even be used freely, providing quick and precise assessments, and providing specialised services for academic writing purposes such as checks plagiarism, (Muhammad Nova, 2018). Research conducted by Purwanto (2017) also reinforces Grammarly's greatness that this program is beneficial in finding dominant grammar errors in writing.

Based on the results of Grammarly assistances, the most writing issues are in the aspect of correctness, with a total of 292 issues. Correctness means that the participants get something troubles with the use of proper grammar, how to spell the words, and punctuation awareness. It is about $49.2 \%$ the common errors came up in every passage of the essay. Purwanto' research confirms that the dominant errors, according to Grammarly, due to the aspect of correctness, particularly covering (1) chance of failures to use prepositions, (2) problems of omitting commas after introductory phrases, and (3) profuse in indefinite articles (Purwanto, 2017). It means that the problematic issues are direct because of the basic knowledge of students to use writing, as a language learning tool that covers linguistics aspects coherently Karen L. Greenberg, 1988). It is not easy to allow students to write such of converting information from what their opinions and perceptions at least there are some problems in writing.

As explained earlier on the critical point of learning grammar, the author tries to analyze student capability in writing. The reason for analyzing student's writing is because the author could understand the level of student writing capacity by analyzing student's writing. The author also could notice the common mistakes of grammar that are often done by students. Thus, it is helpful to determine the problem-solving priority. Which one has to be fixed first depends on the list of 
obstacles. According to DeCapua (Andrea DeCapua , 2008), grammar is a set of rules in language included into perspective and descriptive point of the definition. Perspective grammar means the grammar taught in school, discussed in newspaper and magazines columns on language, or mandated by language academics. It attempts to tell people how they should say something, what words they should use when they need to make a specific choice, and why they should do even if the rule itself goes against speakers' natural inclination. While descriptive grammar means the grammar is what organizes language into meaningful and systematic patterns. It means students have to consider the purpose for which a speaker is using language. When teachers are teaching English to EFL students, it is imperative to consider using formal language context.

The learning process carried out in groups also affects the output of the resulting paper. In the aspect of understanding by using the readability score calculation, which is a score that shows the level at which an article can be read and understood by the reader. Then, the author emphasizes that the essay writing written by students is still at the level of high school students' writing. This issue means that the quality of written by students is not comparable to what their level of education currently at. Some factors can be direct causes, including the average of words and sentences length, the content of new words, and the complexity of grammatical language uses, (J. C Richards and R Schmidt, 2020). In the other hand, readability also can be reasoned by internal factors from the reader, included anxious and motivation, and the legibility of written prints, (K Johnson, 1998).

The author intends to emphasize aspects of readability in one of the research discussion since the software used, Grammarly, accommodates a complete package of automatic-writing assessments, including readability scores. However, readability is delightful to discuss since its usefulness in language learning. Zamanian and Heydari (2012) note some advantages of the readability formula, here are: 1) the formula measures how the grade-level readers are able to read in particular texts; 2) the readability formula is timeless, moneyless, and energyless for deciding which text is too hard and too easy for readers; 3) the formula need particular text to do measurement since it only needs importing the document to get the score; 4) Nowadays, the readability formula is performed by ICT; 5) it also helps writers modify their essay into pure language. Due to the benefits, for this case, Janan (2018) adds the comprehension aspect of writing in the readability score. Readability score provides teacher and lecturer to enhance students to yield an adequately written material based on the grade-level of the readers. The students are ensured that they can have a sense of awareness what the material for in term of increase the beneficial writing texts.

The study takes place at the Shariah Economic Law, Faculty of Shariah, IAIN Pontianak. The study program engrafts an English language course in its curriculum. This policy is following its education' mission which is to produce professionals who are able and capable to solve the problems of shariah economic law and can compete in the era of globalization with upholding noble morality as their unique identity. In other words, the professionals produced by the academy have lawyer skills plus local wisdom of having Islamic noble values. They need to master English thus that they can get involved in the national, regional and international arena. It is an idea that language learning as a part of communication of ethnography from the implication of social and culture, (Mudjia Rahardjo, 2020). As an inseparable part, human civilization which is rapid-moving, cause people to keep learning. Trough acceptable and suitable learning method, Islamic undergraduate students as the object, CALL is the one solution for a better and foreseeable future. 
Those yearning of the institution, of course, it needs evaluation in any aspect of the educational system. The author desires to evaluate the CALL system that has been done in the project of writing an essay in the working group system. The activities that take place in a series of essay writing appear to be less than optimal if carried out in groups with personnel of each group more than three students. This notice is strengthened by Burke (2011) and Gai Mali(2015), how to encourage motivation, interest, and also creating a satisfying decision to get more information. Even though most students sense benefits, the sustainability of this project is better done independently or in a small amount of 1-3 students. Thus, students become more leverage in the distribution of tasks.

Furthermore, the sustainability of learning programs by integrating technology is something that must be planned. The limitation of the Grammarly program, which is free accessed, seems to be one of the obstacles. Colleges should provide Grammarly facilities that are true of high quality; thus that they can correct the details related to the performance of the writing. Besides that, once again, the instructions for use, teacher facilitator, and network strength are also points that support the success of students in writing English.

\section{CONCLUSION}

To sum up, this work presents how the writing quality of Islamic higher education students can be measured through an online application. The assessment results show that the writing performance of students at this level is quite good even though the student's concern is not from an English study program. The author presents the quantitative results consisting of 1) the aspect of correctness with some 292 cases $(49.2 \%), 2)$ the average score of cases per element sequentially starting from engagement, correctness, clarity, and delivery are 4.8, 24.3, 16.8, and 3.5 with the most cases incorrectness and the least cases are delivery issues, and 3) the level of readability score from written students' material is classified sequentially in the range of 9th-grade education level about 1 document $(8.3 \%)$, 10th-grade education level about six documents (50\%), and college graduated students about five documents (41.7)\%. The phenomenon also indicates that the integration of CALL in the learning process has a positive impact. Nevertheless, in this case, the role of the English lecturer as a facilitator and instructor is obliged to explain in detail the procedures for using the technology before students use it independently. Students can automatically aware which parts are wrong; thus that they make the correction immediately since the direction from their teacher directly.

The next important point is that the professional learning in groups does not show the maximum quality of student writing. Some conclusions from student feedback show that Grammarly use is more appropriate to function in independent learning. However, this learning does not rule out the possibility of being done in groups. It is necessary to consider the number of students involved regarding the learning process with the CALL system is more effective than without CALL. In addition, sustainability to enable Grammarly online in learning to write is urgent. It is necessary to consider a mature learning plan through the integration of CALL. This way is a reinforcement for every student from various fields of science that it is not impossible to encourage quality writing of students by involving qualified lecturers and appropriate applications.

\section{REFERENCES}

Awad, A, "The Most Common Punctuation Errors Made by the English and the TEFL Majors at An-Najah National University," An - Najah Univ. J. Res. 
(Humanities)., $26 \quad$ (2012) $<$ https://journals.najah.edu/article/97/ $>$

Bahadur Rana, Kesh, Use of Educational Technologies in Teaching and Learning Activities: Strategies and Challenges A Nepalese Case (Oslo, 2017)

<https://www.duo.uio.no/bitstream/ha ndle/10852/60803/HEM4390.pdf?seq uence $=1 \&$ is Allowed $=y>$

Bahri, Saiful, and Bambang Sugeng, "Difficulties in Writing in Vocabulary and Grammar of The Second Year Students of SMPN 1 Selong East Lombok West Nusa Tenggara in The School Year 2008/2009," 2009, 1-16 <https://journal.uny.ac.id/index.php/jo e/article/download/197/98.>

Burke, Alison, "How To Use Groups Effectivley," The Journal of Effective Teaching, 11 (2011), 87-95 <https://uncw.edu/jet/articles/vol11_2/ burke.pdf>

Collins, Bryan, "Grammarly Review: Is This Grammar Checker Worth It?," Become a Writer Today $<$ https://becomeawritertoday.com/gra mmar-checker-review-grammarly/> [accessed 9 March 2020]

DeCapua, Andrea, Grammar for Teachers (Boston: Springer US, 2008)

Dembsey, J M, "Closing the Grammarly ${ }^{\circledR}$ Gaps: A Study of Claims and Feedback from an Online Grammar Program," The Writing Center Journal, $36 \quad$ (2017), 63-100 $<$ https://www.jstor.org/stable/442526 $38>$

Dubay, William $\mathrm{H}$, The Principles of Readability (California: Impact Information, 2004)

Gai Mali, Yustinus Calvin, "Motivational Factors in the Indonesian Efl Writing Classroom," Jurnal Pendidikan Bahasa Dan Sastra, 15 (2015), 1 $<$ https://doi.org/10.17509/bs_jpbsp.v1 5i1.794>

Ghavifekr, Simin, and Wan Athirah Wan Rosdy, "Teaching and Learning with
Technology: Effectiveness of ICT Integration in Schools," International Journal of Research in Education and Science, $1 \quad$ (2015), 175 <https://doi.org/10.21890/ijres.23596

Ghufron, Muhammad Ali, and Fathia Rosyida, "The Role of Grammarly in Assesing English As A Foreign Language (EFL) Writing," 12 (2018), 395-403

<https://doi.org/10.21512/lc.v12i4.45 82>

Greenberg, Karen L., "Assessing Writing: Theory and Practice," New Directions for Teaching and Learning, 1988 (1988), 47-59 <https://doi.org/10.1002/t1.372198834 06>

Iqbal, Ichsan, Muhammad Hasan, Ardiansyah Ardiansyah, Syaifullah Syaifullah, Ita Nucholifah, Marluwi Marluwi, and others, Pedoman Akademik Fakultas Syariah Dan Ekonomi Islam Institut Agama Islam Negeri (IAIN) Pontianak (Pontianak: IAIN Pontianak, 2017)

Israelsson, Ann-sofi, Mogens Sandfaer, and Stephan Schwarz, "The Global Village Come True: High-Tech Information Network in High Energy Physics," in IATUL Proceedings, 1991, pp. 137-47 $<$ https://docs.lib.purdue.edu/iatul/199 1/papers/26>

Janan, Dahlia, and Sultan Idris, "Readability: The Limitations of an Approach through Formulae," in The British Educational Research Association Annual Conference, 2012, pp. 1-16 <http://www.leeds.ac.uk/educol/docu ments/213296.pdf.>

Johnson, K, "Readability," 1998 <http://www.timetabler.com> [accessed 18 February 2020]

Karyuatry, Laksnoria, Muhammad Dhika Arif Rizqan, and Nisrin Adelina Darayani, "Grammarly As A Tool To Improve Students' Writing Quality: 
Free Online-Proofreader Across The Boundaries," Edulitics Journal, 3 (2018), $36-42$ $<$ https://doi.org/10.30595/jssh.v2i1.22 97>

Krasnikov, Denys, "Grammarly Opens New Kyiv Office as Demand Rises for Help with English," July 6, 2018 <https://www.kyivpost.com/technolog y/grammarly-opens-new-kyiv-officeas-demand-rises-for-english-

help.html?cn-reloaded $=1>\quad$ [accessed 18 February 2020]

Kurtz, L. R., Gods in the Global Village: The World's Religion in Sociological Perspective (California: Pine Forg Press, 2007)

Lahuerta, Ana Cristina, "Study of Accuracy and Grammatical Complexity in EFL Writing," International Journal of English Studies, $18 \quad$ (2018), 71-89 <https://doi.org/10.6018/ijes/2018/1/2 58971>

Mansfield, Gillian, and Franca Poppi, "The English as a Foreign Language / Lingua Franca Debate: Sensitising Teachers of English as a Foreign Language Towards Teaching English as a Lingua Franca," Profile Issues in Teachers' Professional Development, 14 (2012), 159-72 $<$ https://files.eric.ed.gov/fulltext/EJ10 51655.pdf>

Nachoua, Hassina, "Computer-Assisted Language Learning for Improving Students' Listening Skill," Procedia Social and Behavioral Sciences, 69 (2012), 1150-59 $<$ https://doi.org/10.1016/j.sbspro.2012 $.12 .045>$

Neill, Ruth O, and Alex M T Russell, "Stop! Grammar Time: University Students , Perceptions of the Automated Feedback Program Grammarly,” 35 (2019), 42-56 <https://doi.org/10.14742/ajet.3795>

Nova, Muhammad, "Utilising Grammarly in Evaluating Academic Writing: A Narrative Research on EFL Students,"
Premise Journal, 7 (2018), 80-96 $<$ https://doi.org/doi.org/10.24127/pj.v 7i1>

Nurlaili, "An Error Analysis on The Use of Punctuation Marks in Students' Writing (A Study at Second Semester Students of English Department of Universitas Muhammadiyah Surakarta).," 2018 <http://eprints.ums.ac.id/65167/12/N ASKAH PUBLIKASI REVISIFar.pdf.>

Parra, G. Lorena, and S. Ximena Calero, "Automated Writing Evaluation Tools in The Improvement of The Writing Skill," International Journal of Instruction, 12 (2019), 209-26 <https://doi.org/10.29333/iji.2019.122 $14 \mathrm{a}>$

Pim, Chris, "Emerging Technologies, Emerging Minds: Digital Innovations within the Primary Sector," in Innovations in Learning Technologies for English Language Teaching, ed. by Gary Motteram (London: British Council, 2013), pp. 15-42

Purwanto, Sugeng, "Grammar Matters: A Study of Free Writing Performance of the Sixth Semester Students," Universitas Stikubank, 12 (2017), 1017

<https://www.unisbank.ac.id/ojs/index .php/fbib1/article/view/5110>

Qassemzadeh, Abolfazl, and Hassan Soleimani, "The Impact of Feedback Provision by Grammarly Software and Teachers on Learning Passive Structures by Iranian EFL Learners," Theory and Practice in Language Studies, 6 (2016), 1884-94 <https://doi.org/http://dx.doi.org/10.1 7507/tpls.0609.23>

Rahardjo, Mudjia, "Social and Cultural Aspects of Language: Its Implication in Language Teaching," UIN MAULANA MALIK IBRAHIM MALANG, 2010 <https://www.uinmalang.ac.id/r/100301/social-andcultural-aspects-of-language-itsimplication-in-language- 
teaching.html> [accessed 9 March 2020]

Richards, J. C, and R Schmidt, Longman Dictionary of Language Teaching and Applied Linguistics (New York: Person Education, 2002)

Salman, Huda D, May Estefan, and Nahi Y Yaseen, "Errors in Using Punctuation Marks in Selected Scientific Writing Committed By Non- Native Postgraduate," Scientific Research Journal (SCIRJ), V (2017), 7-18 <http://www.scirj.org/papers0417/scirj-P0417396.pdf>

Sermsook, Kanyakorn, Jiraporn Liamnimitr, and Rattaneekorn Pochakorn, "An Analysis of Errors in Written English Sentences: A Case Study of Thai EFL Students," English Language Teaching, 10 (2017), 101 <https://doi.org/10.5539/elt.v10n3p10 $1>$
Stannard, Russell, and Anthony 'Skip' Basiel, "A Practice-Based Exploration of Technology Enhanced Assessment for English Language Teaching," in Innovations in Learning Technologies for English Language Teaching, ed. by Gary Motteram (London: British Council, 2013), pp. 147-73

Wang, Ya-huei, and Hung-Chang Liao, "Learning Performance Enhancement Using Computer-Assisted Language Learning by Collaborative Learning Groups," Symmetry 2017, 9 (2017) <https://doi.org/10.3390/sym9080141 $>$

Zamanian, Mostafa, and Pooneh Heydari, "Readability of Texts: State of the Art," Theory and Practice in Language Studies, 2 (2012), 43-53 $<$ https://doi.org/10.4304/tpls.2.1.4353> 